\title{
WHO'S AFRAID OF ISLAMIC FEMINISM, AND WHY? - RAISING VOICES THROUGH EDUCATION ${ }^{1}$
}

\section{QUEM TEM MEDO DO FEMINISMO ISLÂMICO E POR QUÊ? - ERGUENDO VOZES ATRAVÉS DA EDUCAÇÃO}

\author{
Renan de Souza ${ }^{2}$
}

\begin{abstract}
Resumo: 0 artigo apresenta o poder do feminismo islâmico, um movimento que tem chacoalhado as estruturas patriarcais do mundo islâmico a medida em que as mulheres têm mais acesso à educação. Com base nesse fato, a pesquisa afirma que essa movimentação originada no acesso à educação tem gerado desconforto ao patriarcado, mas principalmente aos fundamentalistas que se veem ameaçados pelo poder das mulheres que buscam uma reinterpretação do Alcorão extraindo uma mensagem de igualdade das escrituras sagradas. O feminismo islâmico, não sendo um movimento uniforme, pois contém visões distintas e disputas de narrativas em seu interior, é exposto aqui sob o olhar de autoras e pesquisadoras, como Fatema Mernissi e Amina Wadud. Em seguida, é apresentado um contraponto com a visão fundamentalista, a resposta das feministas e o exemplo da jovem Malala Yousafzai como uma referência para justificar a hipótese original de que os fundamentalistas percebem as feministas islâmicas como uma ameaça.
\end{abstract}

Palavras-chave: Feminismo, Movimento Feminista Islâmico, Patriarcado, Autoras Feministas Islâmicas.

\begin{abstract}
The Islamic Feminism is a powerful movement which is shaking the patriarchal structure in the Muslim world, since women have largely granted accesses to education. Even though, the movement is not uniform, and it gathers many different voices even, sometimes, disagreeing of its fundamental goals. The essay states that the reinterpretation of the Quranic message - originated in solid education - by the feminists claiming equality in the society is perceived as a threat by the fundamentalist - and in some cases by members of the Political Islam group - and offers a critique of the mainstream male Islamic discourse, based on some Islamic feminist authors interpretation. Ultimately, the essay finishes presenting the case of Malala Yousafzai as a reference. Furthermore, the essay grounds its analyses juxtaposing various interpretations within this movement and among relevant authors and scholars such as Fatema Mernissi and Amina Wadud. It also presents the discussions from two different angles before stating the conclusion of the research.
\end{abstract}

Keywords: Feminism, Islamic Feminist Movement, Patriarchy, Islamic Feminist Authors.

\section{Introduction}

This essay will argue that the fundamentalists, and those who are in favour of maintaining the patriarchal structure in the Muslim world, are afraid of Islamic Feminism, a time-changing movement. However, Islamic Feminism is not unique or uniform. The movement is quite the

\footnotetext{
1 This article is partially based on an essay submitted in 2019 by the author to the examination of the Master's Degree module Middle Eastern and Islamic Thought: Political Philosophy in a Comparative Perspective at Goldsmiths, University of London.

2 MA International Relations, Goldsmiths, University of London - UK. Specialist in International Relations, Fundação Armando Álavares Penteado - FAAP. Journalist, Universidade Metodista de São Paulo - UMESP. The author is a Brazilian journalist and scholar focused on researches on Arab and Islamic affairs, politics of the Middle East, and Security Studies in International Relations. ORCID https://orcid.org/0000-00029065-4029. Link para o currículo Lattes http://lattes.cnpq.br/6322019881122931 and https://www. linkedin.com/in/renanazuos/.Contact: renan.azuos@gmail.com.
} 
opposite, and there are many different voices. Even the Muslim women themselves can be afraid of the outcome of reshaping the actual order and structure of the Muslim society.

Nevertheless, this essay focus on the fundamentalists as the primary response to the topic presented. Furthermore, it also recognises that the category of fundamentalism is highly problematic once the adversaries of the feminists can be also found in groups representing Political Islam or the Islamism.

Having mentioned that, this essays grounds its answer on the perspective of the fundamentalism seeking for one specific identity within the Muslim World. However, this movement has been challenged by non-fundamentalist women who are claiming equality in society. This is a conflict of interest between these two distinct groups. As exemplified by Mernissi (2009: 207) "if fundamentalists are calling for the return of the veil, it must be because women have been taking off the veil." This statement comes across with the argument defended by this essay of fundamentalists as those who are afraid of Islamic Feminism as an external force to undermine their identity vision of the Muslim world.

To address the given question adequately, this essay will be structured in three sections. The first will be devoted to discussing how Islamic Feminism is challenging the classical view of the religion according to some key scholars, such as Fatema Mernissi and Amina Wadud. This unit will also address the message of equality extracted from the interpretation of the Quran and how it challenges the patriarchal Islamic society.

The following section will be used to discuss why Islamic Feminism is perceived as a threat by the fundamentalists and those who are in favour of maintaining the male-dominated patriarchal structure. The last section will use a recent case to explain and support the original claim. The aim here is to present Malala, who challenged the Taliban's role and rules and was shot in the head by a member of the fundamentalist group in Pakistan.

\section{Challenging the classic view of Islam}

Looking to the past, women have not been treated as equal as men since the beginning of Islam in Arabia in the early 600s. Despite the fact that Islam claims that men and women are equals in the sight of God, women's access is denied in some aspects of Islamic life (John Esposito, 2019).

The slight access of women to universities comes during the 1800s (Esposito, 2019), and this movement has been increasing recently if we look into the generation of people. As a historical argument, this essay presents a study conducted by Pew Research, one of the most comprehensive ever made, shedding light on this issue. According to the analyses, the youngest generation of Muslim (born from 1976 to 1985) have more formal studies compared to the oldest generation (born from 1936 to 1955). Men still are more educated than women in the Muslim world. Nevertheless, women have made more gains than men, and the gap is lower than was in the past (see figure 1). 


\section{Globally, Muslim gender gap in years of schooling has narrowed}

Average years of schooling for Muslim men and women across three generations

15 years

10

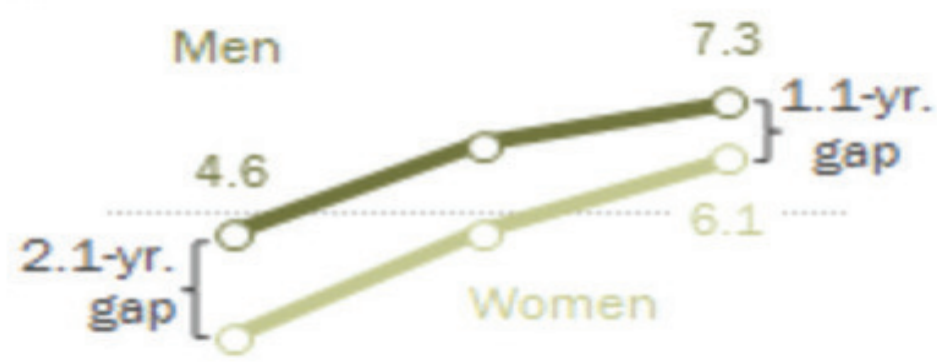

0 2.5

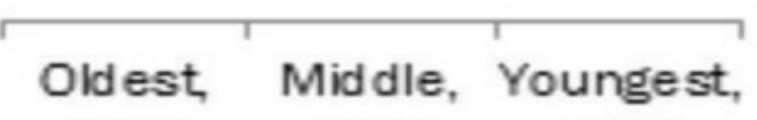
ages ages ages 55-74 35-54 25-34

Note: The oldest, middle and youngest cohorts were born 1936-1955, 1956-1975 and 1976-1985, respectively, and were ages 55-74, 35-54 and 25-34 as of 2010 . Gaps are calculated based on unrounded numbers.

Source: Pew Research Center analysis. See Methodology for more details.

"Religion and Education Around the World" PEW RESEARCH CENTER 
If we look primarily to some countries in the Gulf region, such as Qatar, Kuwait Bahrain, and Saudi Arabia, more women hold post-secondary degrees than men, reversing the classical gender gap in the Muslim society (see figure 2).

\section{Share of Muslims in Gulf states receiving higher education has grown across generations, but differs by gender}

$\%$ with higher education, by gender

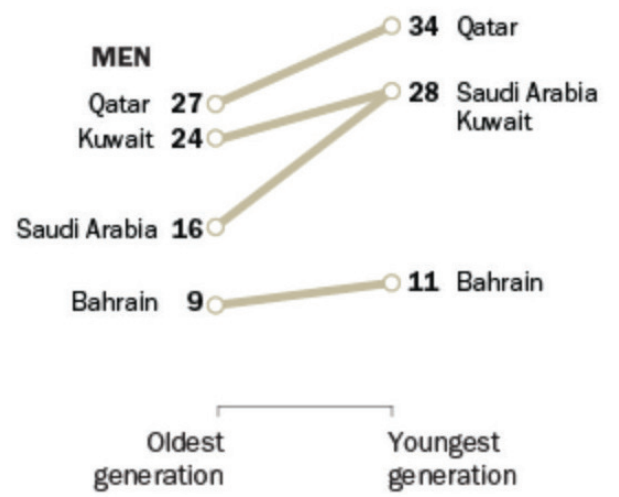

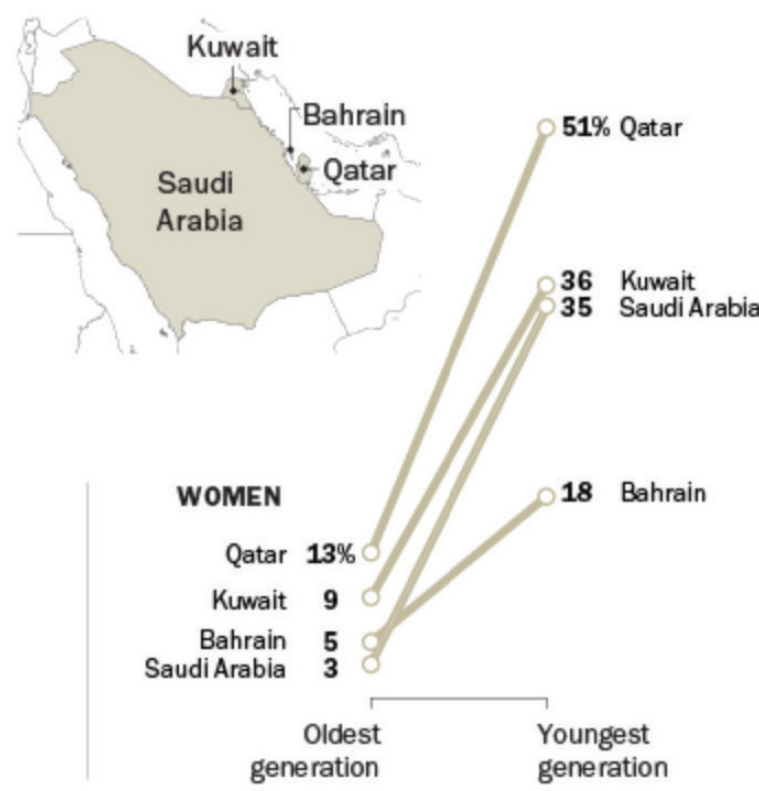

Note: The oldest and youngest cohorts were born 1936-1955, and 1976-1985, respectively, and were ages 55-74 and 25-34 as of 2010. Data for Muslims in these four countries reflect only educational attainment for citizens. See Methodology for more details.

Source: Pew Research Center analysis.

"Religjon and Education Around the World"

PEW RESEARCH CENTER

Figure 2 - The gender gap has reversed regarding higher education in Gulf Countries. Source: Pew Research Centre

The trend also has been confirmed in recent years. According to a UNESCO report, published in 2018, the percentage of female students in higher education in the Gulf states is raising (see figure 3 ). 


\begin{tabular}{|c|c|c|c|}
\hline & UAE & Qatar & Kuwait \\
\hline Total population & 9.4 millio & 2.6 million & 4.1 million \\
\hline GDP per capita US\$ & 72,419 (WB) & $127,660(\mathrm{WB})$ & 71,887 (WB) \\
\hline $\begin{array}{l}\text { Gvt expenditure } \\
\text { on education } \\
\% \text { of GDP }\end{array}$ & 1.11 (UIS) & 3.6 (UIS) & 3.8 (UIS) \\
\hline $\begin{array}{l}\text { R\&D expenditure } \\
\% \text { of GDP }\end{array}$ & 0.49 & $0.479(W B)$ & $0.302(\mathrm{WB})$ \\
\hline Nos. of HEls ${ }^{5}$ & $12(3) 51$ & 7 & 12 \\
\hline $\begin{array}{l}\text { Tertiary } \\
\text { enrolment }\end{array}$ & 143,000 & 150,000 & \\
\hline$\%$ of Females ${ }^{6}$ & $>50$ & 60 & ca. 70 \\
\hline Higher education GER \% & & 14.518 (WB) & 27.027 (WB) \\
\hline $\begin{array}{l}\text { Unemployment } \\
\text { rate for HE graduates }\end{array}$ & $\begin{array}{l}\text { Negligible, but } \\
\text { many women } \\
\text { outside the } \\
\text { economy }\end{array}$ & $\begin{array}{l}\text { Negligible, but } 60 \% \\
\text { of women } \\
\text { outside the } \\
\text { economy }\end{array}$ & $\begin{array}{l}\text { Unemployment } \\
\text { rate } 17.5 \% \text {, many } \\
\text { women outside } \\
\text { the economy }\end{array}$ \\
\hline
\end{tabular}

${ }^{5}$ Numbers of Universities: Ranking Web of Universities, July 2017

${ }^{6}$ Percent Females, from various sources;

7 Unemployment rates from various sources. The main sources the World Bank (WB), and the Unesco Institute for Statistics (UIS).

\begin{tabular}{|c|c|c|c|}
\hline Oman & Saudi Arabia & Bahrain & Yemen \\
\hline 4.6 million & 33.0 million & 1.5 million & 28.5 million \\
\hline 46,698 (WB) & $20,55,158$ (IMF) & 50,764 (IMF) & 2,375 (IMF) \\
\hline 4.9 (UIS) & 6.8 (UIS) & 2.6 (UIS) & $?$ \\
\hline 0.246 (WB) & 0,818 (WB) & 0.101 (WB) & \\
\hline 33 & 56 & 45 & 25 \\
\hline & 3.6 million & 55,000 & \\
\hline & 54 & & 10 (?) \\
\hline & 63.066 (WB) & 41.309 (WB) & $?$ \\
\hline $12 \%$ & $30-34 \%$ for women & Ca. $25 \%$ & $\begin{array}{l}\text { Total female } \\
\text { unemployment 78\% }\end{array}$ \\
\hline
\end{tabular}

Figure 3 - The percentage of female students in the UAE, Qatar, Kuwait and Saudi Arabia is higher than 50\%. Source: UNESCO 
ensaio

The same pattern has also been reported in some countries of MENA (the Middle East and North Africa) region (see figure 4 and 5).

\begin{tabular}{|l|l|l|l|}
\hline Indicators & Algeria & \multicolumn{2}{l}{ Libya } \\
\hline Total population & 40,6 million & 6,4 million \\
\hline GDP per capita US\$ & $15,000 \$$ & $14,200 \$$ \\
\hline Gvt expenditure on HE \% GDP & $1,2 \%$ & NA* \\
\hline Gvt expenditure on education \% of GDP & 4,4 & NA \\
\hline R\&D expenditure \% of GDP & $0,07 \%$ & NA \\
\hline Nos. of public HEls & $\begin{array}{l}50 \text { Universities } \\
62 \text { HEI }\end{array}$ & $\begin{array}{l}18 \text { universities } \\
16 \text { HEI }\end{array}$ \\
\hline University enrollment (public) & 1,5 million & 372,010 \\
\hline Percentage of female enrollment & $60 \%$ & $51,38 \%$ \\
\hline Higher education GER \% & $36,92 \%$ & NA \\
\hline $\begin{array}{l}\text { Unemployment } \\
\text { rate for HE graduates }\end{array}$ & $24,8 \%$ & $50 \%$ \\
\hline QA System & $\begin{array}{l}\text { Apists formally } \\
\text { Apation? }\end{array}$ & $\begin{array}{l}\text { Exists formally } \\
\text { Application? }\end{array}$ \\
\hline
\end{tabular}

DATA SOURCES: UNESCO Institute for Statistics (UIS); World Bank 2016; World Data Atlas; OECD Database; Ministrie of

* NA= Not available

\begin{tabular}{|c|c|c|c|}
\hline Mauritania & Morocco & Sudan & TUNISIA \\
\hline 4,3 million & 35,9 million & 40,1 million & 11,5 million \\
\hline $4,400 \$$ & $8,400 \$$ & $4,500 \$$ & $11,700 \$$ \\
\hline NA & $1,1 \%$ & NA & $1,7 \%$ \\
\hline 2,93 & 5,26 & 2,22 & 6,26 \\
\hline NA & $0,73 \%$ & $0,23 \%$ & $0,68 \%$ \\
\hline $\begin{array}{l}1 \text { university } \\
4 \mathrm{HEI}\end{array}$ & $\begin{array}{l}14 \text { Universities } \\
143 \mathrm{HEl}\end{array}$ & & $\begin{array}{l}13 \text { universities } \\
195 \mathrm{HEI}\end{array}$ \\
\hline 20,298 & 750,000 & 570,000 & 340,000 \\
\hline $33 \%$ & $48,5 \%$ & $52,2 \%$ & $61,5 \%$ \\
\hline $5,34 \%$ & $28,14 \%$ & $16,32 \%$ & $34,61 \%$ \\
\hline NA & $33 \%$ & $79,5 \%$ & $29,2 \%$ \\
\hline $\begin{array}{l}\text { Exists formally } \\
\text { Application? }\end{array}$ & $\begin{array}{l}\text { Exists formally } \\
\text { Application? }\end{array}$ & NA & $\begin{array}{l}\text { Exists formally } \\
\text { Application? }\end{array}$ \\
\hline
\end{tabular}


ensaio

\begin{tabular}{|c|c|c|c|c|}
\hline Iraq-Federal & KRI & Palestine & Egypt & Syria \\
\hline 39 million & 5,61 million & 4.67 million & 91.5 million & $18,792,029$ \\
\hline $4,609.6 \$$ (WB) & $4,188.9 \$$ (WB) & $1,745.9 \$$ (WB) & $\$ 3,614.7$ (WB) & $2000-3000 \$$ \\
\hline $1.11 \%$ (UIS) & & & & $4.97 \%$ (UIS) \\
\hline $4.87 \%$ (WB) & & $1.32 \%$ & $6 \%$ & $\begin{array}{l}12 \% \text { of public } \\
\text { sending }\end{array}$ \\
\hline $22,8 \%$ (WB) & & $3 \%$ (WB) & & \\
\hline 0,037\% (WB) & - & $0,492 \%(W B)$ & $0,723 \%$ (WB) & - \\
\hline 134 & & 52 & 43 & 27 \\
\hline 78 & & $29^{10}$ & 20 & \\
\hline & & 220,000 & $2.87 \mathrm{mln}$. & 486,524 \\
\hline & & $60 \%(\mathrm{WB})$ & & \\
\hline $16 \%(W B)$ & & $25.8 \%$ (WB) & $36.23 \%$ (WB) & $44,05 \%$ (WB) \\
\hline & & & $34 \%$ (WB) & \\
\hline & & $\begin{array}{l}\text { PES }^{12} \\
\text { NGOS }\end{array}$ & & \\
\hline
\end{tabular}

Figure 4 - The percentage of female students in Algeria, Libya, Sudan and Tunisia is higher than 50\%. Source: UNESCO 


\begin{tabular}{|c|c|c|}
\hline Indicators / Countries & Lebanon & Jordan \\
\hline Total population & 4.5 million & 9.45 million \\
\hline GDP Per Capita (\$) & $7,914.0 \$(W B)$ & $4,087.9 \$$ (WB) \\
\hline Govt. expenditure on higher education as a $\%$ of GDP & $0,74 \%$ (UIS) & $0,46 \%$ (UIS) \\
\hline Govt. expenditure on education as a \% of GDP & $2.46 \%$ & $12,37 \%$ \\
\hline $\begin{array}{l}\text { Expenditure on tertiary education as a \% of } \\
\text { expenditure on education }\end{array}$ & $28,74 \%$ (WB) & $1,4 \%(W B)$ \\
\hline$\%$ GDP on research (R\&D Expenditure) & & $0,15 \%(W B)$ \\
\hline No. of HEls ${ }^{8}$ & 46 & 78 \\
\hline No. of Public HEls ${ }^{9}$ & 1 & 17 \\
\hline University Enrollment & 196,119 & 337,500 \\
\hline Percentage of Female Enrollment & $57,17 \%$ (WB) & \\
\hline Higher Education GER & $38.48 \%(\mathrm{WB})$ & $44,87 \%$ (WB) \\
\hline Unemployment rate for $\mathrm{HE}$ graduates & $36.1 \%(W B)$ & $34 \%(W B)$ \\
\hline Cost-sharing practices ${ }^{11}$ & $\begin{array}{l}\text { Indirect } \\
\text { Std. loans }\end{array}$ & \\
\hline
\end{tabular}

\footnotetext{
s Number of higher education institutions provided from ministry websites and verified by ministry focal points through interviews

- Number of public higher education institutions provided from ministry websites and verified by ministry focal points through interviews

10 including those of the Palestinian Auhtorities, excluding UNRWA institutions

Information on Lebanon and Palestine is received from relevant ministries of higher education

12 Parallel Education System
}

General sources of information:

https://data.worldbank.org/indicator/GB.XPD.RSDV.GDZZS?locations=LB-IQ-JO-PS

http//www.krso.net/uploads/pdf/brushurEn.pdf

Figure 5 - The percentage of female students in Lebanon and Palestine is higher than 50\%. Source: UNESCO

These data offer an insight into female education in the MENA region. Although women are present in higher numbers at universities, from the other side, the unemployment rate among them is quite high, what suggests a gap between gaining entry to higher education and their access to the labour market.

However, this is not the only contradiction in the Muslim world. There are still several gaps to look at. Two of those cases are Afghanistan and Pakistan. Proportionally, there are more boys at school than girls in Pakistan. The chasm between them is about 10\% (Malik, 2018) (see figure 6). 


\section{Access to education in Pakistan by gender}

Students aged 5-17, numbers in millions

Boys Girls

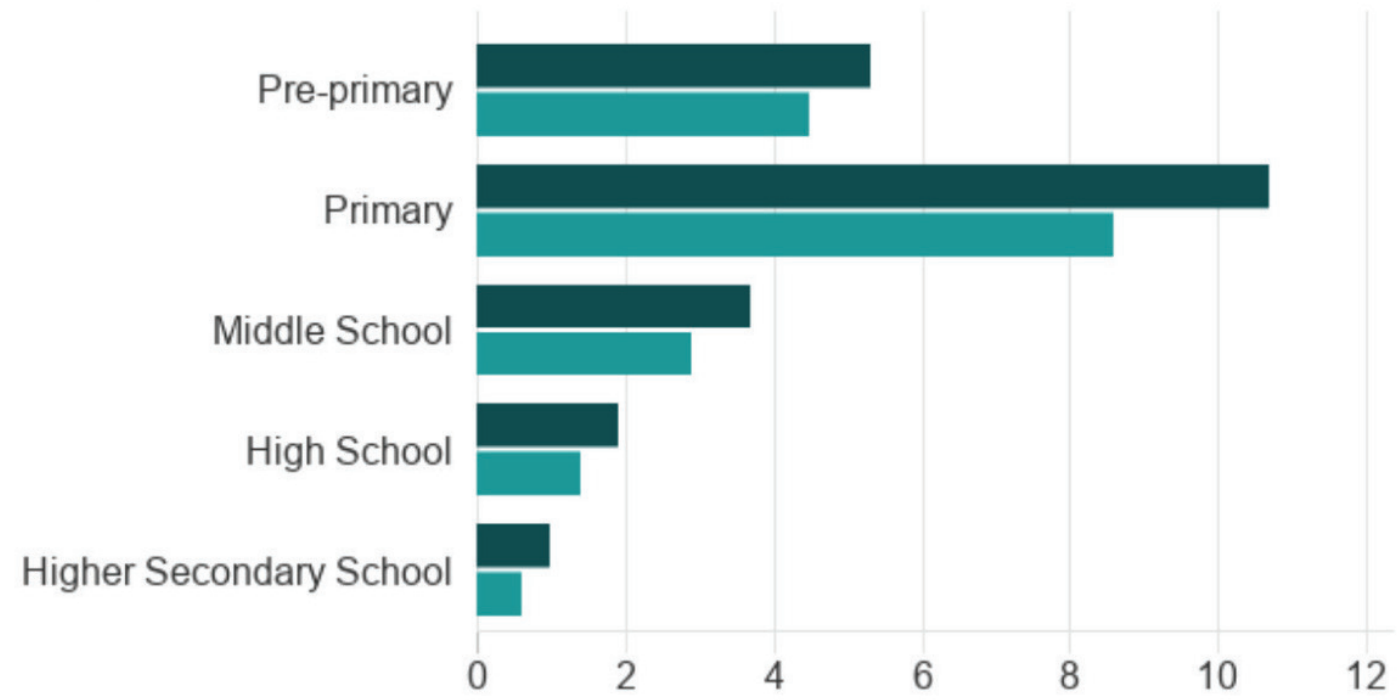

Figure 6 - The girls are less privileged in terms of access to education in Pakistan. Source: Pakistan Ministry of Education/BBC

Regarding Afghanistan, the female access to higher education is deficient, according to the World Bank's figure from 2015. In that year, women were accounted only for $13,78 \%$ of all higher education programs (bachelor, masters, and $\mathrm{PhD}$ ). While men represented $86,22 \%$ (see figure 7) (World Bank, n.d.). These statistics reveal a dramatic gap between male and female, as this essay will shed light in the upcoming units.

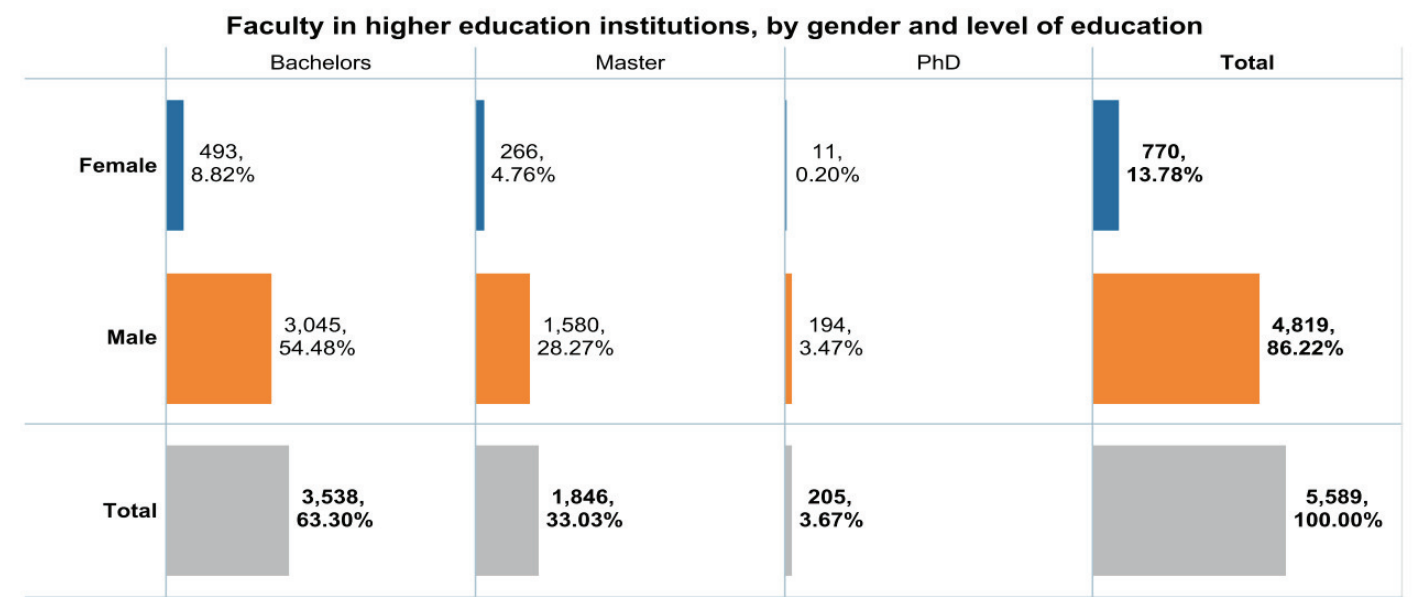

Figure 7 - The girls are less privileged in terms of access of education in Pakistan. Source: Ministry of Higher Education - Afghanistan 
Why are the data so essential to address the original statement given to this essay? Because, in the past of the Muslim world, knowledge, and universities were restricted to the men of the elite. The mass access to the universities reveals a shift of distribution, management, and utilisation of knowledge and information (F. Mernissi, 2009: 209) "and knowledge is power" (Mernissi, 2009: 209).

Detailing these data, this essay intends to argue that access of women to education is one the main preoccupation of the fundamentalists since places such as schools and universities are the primary source of feeding knowledge for feminist resulting in critics and changes to the actual male-dominated structure. The education of women reshaped the traditional concepts, the definition of space, and sex roles (Mernissi, 2009: 210). A new scope that, perhaps, not all the fundamentalists know how to deal with and possibly would name it as fitna (disorder) or portraying the well-educated generation of women as the enemies of the Islam.

This access to knowledge has been also giving women another possibility, unexplored before, of reinterpreting the Qur'an. Amina Wadud (2006: 202), for instance, goes deep in a qur'anic interpretation by deconstructing the idea of the Holy Book being gendered. Using the Qur'an as her primary source of argument, she defends that Arabic grammar carries out gender marks, which could potentially lead to a misinterpretation of gender attribution. Wadud also offers enlightening interpretations affirming that the Qur'an foresees women's right to inheritance, independent property, divorce, right to testify and prohibits the violence against women and girls (Wadud, 2006: 202).

However, the views presented by Wadud (2006) and Mernissi (2009) are not unique and uniform in the Muslim world. Islamic Feminism is complex and cannot be considered as an only-one-voice movement. There are several interpretations to it. If we consider the Egyptian Islamic fundamentalist scholar, Heba Raouf Ezzat, she would argue that the movement is not considering wider international questions.

Heba Raouf Ezzat put on doubt the movement's goal by saying how equality can be achieved within social structures which are constantly seeing the increase of social disparities, poverty and deterioration of basic human life under the rules of the International Monetary Fund and World Bank. To Ezzat's mind, the answer to those questions would lead to an intense discussion of the state social and economic policies. However, since the feminists are eager to see their agenda translated into material changes, they prefer rather to not disturb the regime on this topic (Ezzat, 2002).

The Egyptian thinker also argues that the conditions to legitimate the feminist discourse are restrictive and the law, as a bargaining instrument, has been abused by states and by the feminists. Hence, according to her, the feminist movement has become one of the allies of the regimes against the "fundamentalist" threat (Ezzat, 2002). The point here is to show how divided the interpretation of the Islamic Feminism can be inside the Muslim world, and how a woman can be also against the movement. 
Nonetheless, this essay will stick with the original claim of the Muslim women reinterpreting Islamic traditions and history, such as Omaima Abou Bakr. In her works, she proposed that, in order to the struggle of equality to be meaningful, it needs to be used in a discriminating way for those who both criticise the Islamic tradition and, at the same time, create solutions based and inspirited by the Islamic values (Mervat Hatem, 2019: 22-35). Abou Bakr shows her faith in Islam - through the words - and answers the gender inequality found in her religion, as follow:

I thank God profusely for being a Muslim. Islam is a religion of truth, justice, equality and compassion. It does not sanction injustice or falsehood in the public level, in the social sphere, or even inside the family, at the individual level or in personal interactions. I also thank him for bestowing his blessing on me so that I am capable of reading his words, reflecting on and contemplating their glories, ... for giving me a mind that understands, ponders and weighs thoughts and a heart that is full of his love and is desirous of his approval... . (Hatem, 2019: 22-35).

This passage exemplifies, explicitly, how the interpretation of Islam through the feminist perspective is made. Abou Bakr is not trying to get rid of the religion. It is quite the opposite. She starts thanking God for being part of the Muslim community, as a sign of reaffirmation of her faith. The following sentence justifies the origin of Islam as an answer to inequality, reminding the real meaning of the religion. Hence, the next words are dedicated to express how proud she is to be capable of understanding, reflecting, and putting into practise Allah's words. This approach could be precious to interpret gender perspective and to understand the religious text from a Muslim woman's perspective (Hatem, 2019: 22-35).

To challenge the classical view and traditions of Islam, women or feminist activists go beyond than just getting access to the knowledge in universities and schools or Qur'anic reinterpretation of the Holy Scriptures. This process also involves recounting the history from a different perspective as, for instance, Aisha's biography, the Prophet's favourite wife. The Islamic feminists emphasise her as having a significant role as the army general during the famous Battle of the Camel (Wadud, 2006). Another vital aspect is given by the fact that the Prophet Muhammed was also resting in her lap when received the Revelation (Wadud, 2006). The importance of Aisha may not be well-highlighted by the men, especially the patriarchists and the fundamentalists. To the feminists, this is not randomly, and the different representations, discourses, and discussions about Aisha's role were part of a deconstructing process in order to achieve alternative definitions to the role that Arab women had in the past of the Islamic history (Hatem, 2019: 22-35).

The debate and questions brought up by the feminists also target the occupation of public and male-dominated spaces intensely. Amina Wadud was an example of how welleducated and empowered feminist may shake the given structures inside of the Islamic society. In an unprecedented move, in 1994, she delivered the Friday Khutbah (sermon) in 
Cape Town, South Africa. Men traditionally do this role (Wadud, 2019). By justifying this landmark changing, which generated widespread criticism for breaking the patriarchal rules, she said: "The Qur'an never says that the imam cannot be a woman and must be a man. Whenever there is a difference in the ijtihad (interpretation) of the Holy Book, we must use our intelligence to understand the real meaning of Islam" (A. Meringolo, 2019).

The occupation of spaces, before dominated only by men -- whether in politics, as head of states, in universities, school or in mosques -- as Amina Wadud did, is a central issue of the feminist struggle. Mernissi (1997: 238) also conceptualised the idea of space by exemplifying the issue as saying that women are disturbing as soon as they appear where they are not expected. Moreover, no one expects to see them in a place where decisions are made. Also, some men may resist sharing their power and, at the same time, they are defenceless since this ongoing process is happening within the legitimate dominant culture (K. Ask and M. Tjomsland, 1998: 62). This movement may be considered as fitna (disorder) to the fundamentalists and a source of threat for those who are holding power. The topic will be explored in this essay in the next section.

\section{Why is the Islamic Feminism Perceived as Threat by the Fundamentalists?}

To start the discussion in this chapter, first, it is vital to understand who the fundamentalists are and what are their goals. The fundamentalists are present in countries such as Saudi Arabia, Egypt, India, Iran, Pakistan, Lebanon, Afghanistan, Algeria, Sudan and Palestine and emerged, some organised by groups, as a reaction to humiliation experienced by Middle Eastern societies under the imperialist domination or influence of superpower (Haideh Moghissi 1999: 67). This religious-political movement felt threatened by the destruction of traditional beliefs and practices in their society and the increasing cultural influence of the Western countries (Moghissi 1999: 68). As a solution, the supporters of this wing attempted to mobilise the Muslims against these external forces.

In generic terms, the fundamentalism is an approach towards the past. However, it is not a general past, but a specific and ideal past, which contrasts with the present. This retrieve to the past can be achieved by going back to an original text or by the reformation of society to be built in a copy of the idealised past (Moghissi 1999: 69). To save and reform this society, the fundamentalists seek to establish a genuinely Islamic culture based on an interpretation of the Holy Scriptures and model that was vigorous after the initial Islamic states under the Prophet Muhammad and the four godly khalifs (Moghissi 1999: 69). The fundamentalism anchors its views on the Islam as a totalising force that rules all aspects of the human life in private and public spheres and, hence, are anti-modernity, anti-democracy, and anti-feminism (Moghissi 1999: 70).

From this point, it is possible to foresee a collision course of ideals between the fundamentalists and the Islamic feminists. As naturally anti-feminist, amongst 
fundamentalists, there is a common sense to perceive a threat from the changes in gender relations, triggered by the spread of capitalism and feminism. Controlling women and establishing the authority of the patriarchal family are the primary goals in the fundamentalist utopia (Moghissi 1999: 72).

The Islamic feminist movement is doing quite the opposite by questioning and facing the patriarchal structure in the Muslim world. The threat is posed to the fundamentalists also by the fact that the movement is more vocal and more willing than ever to discuss and reform the identity (Wadud, 2006: 204). The feminists, at some degree, are also looking for answers and solutions in the past, but in order to overcome the inequality in history and shed light on building a prospective future. On the other hand, the fundamentalists are revisiting the past to impose it to present and to keep it to prospect, denying any possible further development regarding gender, democracy, or modernity. Revisiting the past, women are endeavouring to remove the moorings imposed by centuries of patriarchal interpretation and practices (Wadud, 2006: 204).

Those practices can also include the coercive use of the veil, imposed by the fundamentalists in some countries. This essay is not arguing that the use of the veil does not represent some source of empowerment to the women. To some of them, the adoption of the dress does not declare their places as to be at home. However, on the contrary, it legitimises their presence outside of it (Ask and Tjomsland, 1998: 61). Nonetheless, the focus here is to clear up on legislation and government ruling to make the use of the hijab mandatory, such as in Iran, where women are forced upon to harsh legal and extra-legal punishments. In Sudan, the imposition of the Islamic dress was one of the first acts of the fundamentalists when they assumed power after 1989. Women can be intimidated and threatened by Hamas at the Gaza Strip or West Bank if they refuse to wear the headscarves (Moghissi 1999: 43). Reports of coercion and intimidation also can be found in Egypt and Jordan (Moghissi 1999: 44).

The debate may also come accompanied by the idea of the veil as a protecting shield against men's sexual advances towards women. However, Moghissi (1999: 45) argues that the veiling and the strict Islamic code for enforcing public morality have never proved sufficient to protect women against rape committed, indeed, by some of her Muslim brothers. Regarding this question, Moghissi (1999: 46) also emphasises that the justification to the veil or other Islamic practices are inaccurate and politically quite conservative.

There is no consensus in the Muslim world regarding the use of the veil. It can be seen and read as a tool of empowerment to the women to reaffirm their presence or religious beliefs. However, this essay intends to highlight how dangerous the discourse of the veil can be when fundamentalists are rulers and perceive the Islamic feminism as a threat to their goal of bringing back the Islamic practices from the so-called "Golden Age". What this essay assumes is to classify the Islamic fundamentalism as one of the most potent ideological, political, and philosophical challenges to feminism, women's autonomy, and their right to choose (Moghissi 1999: 46). 
To some fundamentalists, feminism, additionally, can be considered as part of the imperialist world's plot to destroy Islamic society and this narrative has led them to impose women as the central vision in preserving the moral character of a nation (Watt, 1989: 115). Therefore, this is the reason why the changes are shaking the foundations of the Muslim world, as argued by Mernissi (2011: 185), to the dismay of rigid conservatives desperately worried with the static traditions. This exaggerated attempt to control women can also be dangerous, as this essay is going to explore in the next section.

\section{The Malala's Case}

Perhaps, one of those most important symbols of the recent years in the women's struggle for their rights is the Pakistani activist Malala Yousafzai. Publicly critical and vocal against the Taliban's prohibition on the education of girls, she survived to an attempt of assassination plot of the fundamentalist group in Pakistan (Naomi Blumberg, 2019), in 2012, when she was 15 years old.

Her history comes across with some concepts explored by this essay in the previous two sections. It is proven by the fact that the Taliban invaded the Swat Valley, in Pakistan, and started to impose a strict view of the sharia law (a religious law extracted from the Islamic traditions) destroying, shutting down and also carrying out suicide attacks against girls' schools. The fundamentalists also banned women from any active role in society (Blumberg, 2019). After a widespread backlash in the country against those measures, in 2009 , the Taliban lifted the restrictions allowing girls to attend the school on the condition they wear burkas. However, this reality lasted for a few months until the returning of the fundamentalist violence (Blumberg, 2019).

Still, in 2009, Malala Yousafzai continued with her advocacy in media outlets, was nominated human rights activist and won the Pakistani National Youth Peace (Blumberg, 2019). Three years later, she was shot in the head by a Taliban gunman on her way from home to school. She survived and in 2014 was the youngest winner of the Nobel Peace Prize (NobelPrize.org, 2019).

The question to pose here is: why is Malala, equipped with pen, pencil, notebooks, books, and knowledge, perceived as a threat by the heavily-armed fundamentalist group Taliban? Reflecting on the Moroccan case, Mernissi argues (2011: 171) that the schooling of girls and the infiltration of women into classrooms is a vast and radical breach in the traditional system. Perhaps, likewise, the fundamentalists were also aware of the Malalaian Theory, that education is the best drone to attack radicalisation of people in underdeveloped tribal regions (Syed Fazl-e-Haider, 2013). Critics of Malala do not want to see "more of her", who challenges the radical and theocratic mindset, emerging as the role models for the young generations in Pakistan (Fazl-e-Haider, 2013). 
Considering the case of Pakistan, the Taliban openly expressed its views to remake the country accordingly to its interpretation of an Islamic state. A country without space for liberal or secular forces. No room for different opinions or criticism, which could be ending up in a death sentence. A nation where women would be banned from employment and education (Fazl-e-Haider, 2013). A similar view is shared by the author Muhammad al-Bahi, who dreaded the consequences of the women's economic independence by saying they would avoid family ties, would decide their future husbands, where to live, whether or not have children. Al-Bahi also assumes that if the men are not in charge of the women, they will lose the sense of human values, and the family entity would be dissolved (William Watt, 1989: 115). Once more, revisiting the last section, this mindset evokes the fundamentalist's view of women as the guardian of morality in the nation. Islamic Feminism seeks to liberate women from this fate. Hence, the movement always will be perceived as a threat to the fundamentalist, who are afraid of those structural changes in terms of tradition.

In Malala's case, it is possible to find the fundamentalist's mindset explored before. Herself described when the Taliban invaded the Swat Valley - where she used to live with her family - and started to broadcast messages encouraging men to go outside. Regarding women, they were advised to stay at home, fulfilling their responsibilities and, just in case of emergency, go outside wearing the veil. Malala expressed confusion by this announcement simply because she read the Qur'an and she could not find written that men should go outside, and women should work the whole day (M. Yousafzai and C. Lam, 2013: 95). Thus, this passage exemplifies, once more, how an empowered Islamic feminist woman can challenge the male-dominated structure of the Muslim world.

\section{Conclusion}

As this essay has shown through three units, the fundamentalists are those who are afraid of the Islamic Feminism. The women's movement has a strong potential to change the patriarchal hierarchy imposed in some Muslim countries. Women are perceived as a threat by the fundamentalists since they can gradually be able to occupy spaces often, before, dominated solely by male figures. Fundamentalists are also afraid of the Islamic Feminism because, according to their views, the women can be read as "westernised" and a threat to the Muslim traditions, hence, to the revivalist mindset of rescuing the Islamic "Golden Age".

Education also plays an essential role in creating the threat understood by the fundamentalists. The result of the education training and schooling of girls and women is a powerful tool to the feminists facing the patriarchal structures. "And knowledge is power" (Mernissi, 2009: 209). Occupying the schools, which in the past were dedicated to the male elite, is also considered as a threat. Reinterpreting the Quranic verses and delivering the Friday Khutbah, as Amina Wadud did, can be translated as losing territories and power. Or even reading the Qur'an as the base to reclaim equality between the sexes can be interpreted 
as an affront. Fundamentalists will never see those steps as progress since, for them, women have their role related to taking care of the house, the family and are seen as the face of the moral values. Any attempt to break this ideology can be translated into fitna (disorder).

When a woman tries to get rid of this restricted view of Islam, she can be targeted and even have her life threatened by fundamentalist men, as we could see in Malala's case. In the end, more than being heard, achieve equality, and occupy spaces dominated by men, the Islamic Feminist struggle is also for power. The same struggle of the fundamentalists who are also seeking power through their religious beliefs. Perhaps the scenario may change when a woman reaches the political power as a head of state and, hence, present bright, new, and powerful ideas towards the liberation of the Muslim women. This is not an easy task. After all, as described before, it is not just the fundamentalists that are afraid of Islamic Feminism, but also some of their Muslim sisters. However, this could be a topic for further discussions.

\section{Bibliography}

Ask, K. and Tjomsland, M. (1998). Women and Islamization. Oxford: Berg. pp.61-62.

Blumberg, N. (2019). Malala Yousafzai / Biography \& Facts. [online] Encyclopedia Britannica. Available at: https://www.britannica.com/biography/Malala-Yousafzai [Accessed 6 Jan. 2019].

Channel 4 News. 2015. Malala Yousafzai: 'I'M A Feminist And A Muslim'. [online] Available at: <https://www.channel4.com/news/malala-yousafzai-im-a-feminist-and-a-muslim> [Accessed 17 May 2020].

Esposito, J. (2019). Women - Oxford Islamic Studies Online. [online] Oxfordislamicstudies. com. Available at: http://www.oxfordislamicstudies.com/print/opr/t243/e370 [Accessed 4 Jan. 2019].

Ezzat, H., 2002. Rethinking Secularism ... Rethinking Feminism. [online] Islam Online Archive. Available at: <https://archive.islamonline.net/17501> [Accessed 17 May 2020].

Fazl-e-Haider, S. (2013). Malala versus Extremism Not Taliban, but Talibanization. [online] Harvard International Review. Available at: https://search.proquest.com/ docview/1470893137?rfr_id=info\%3Axri\%2Fsid\%3Aprimo\&accountid=11149 [Accessed 7 Jan. 2019].

Gibbs, A., 2018. How Nobel Peace Prize Laureate Malala Yousafzai Embraced Feminism. [online] CNBC. Available at: <https://www.cnbc.com/2018/01/31/malala-yousafzai-onfeminism-and-raising-awareness-about-female-rights.html> [Accessed 17 May 2020].

Hatem, M. (2019). In the Eye of the Storm: Islamic Societies and Muslim Women in Globalization Discourses. [online] Muse.jhu.edu. Available at: https://muse.jhu.edu/article/198833 [Accessed 5 Jan. 2019]. 
Wadud, Amina. Islam \& feminism. (2019). [online] Available at: http://www.islamandfeminism.org/amina-wadud.html [Accessed 5 Jan. 2019].

Malik, S., 2018. Reality Check: Are More Girls In Pakistan Going To School?. [online] BBC News. Available at: <https://www.bbc.com/news/world-44717345> [Accessed 17 May 2020]. Meringolo, A. (2019). Amina Wadud, portrait of a Muslim feminist. [online] Reset Dialogues on Civilizations | a venue for all tribes. Available at: https://www.resetdoc.org/story/ amina-wadud-portrait-of-a-muslim-feminist/ [Accessed 5 Jan. 2019].

Mernissi, F. (2011). Beyond the Veil - Male-Female Dynamics in Muslim Society. London: Saqi Books. pp.171-185.

Mernissi, F. (2009). Muslim Women and Fundamentalism in New Voices of Islam: Reforming Politics and Modernity: A Reader. I. B. Tauris \& Company, Limited, pp.205-211.

Mernissi, F. (1997). The Forgotten Queens of Islam. 2nd ed. Minneapolis: University of Minnesota Press, p.238.

Moghissi, H. (1999). Feminism and Islamic Fundamentalism. London: Zed Books. pp.43-72.

NobelPrize.org. (2019). The Nobel Peace Prize 2014. [online] Available at: https://www. nobelprize.org/prizes/peace/2014/yousafzai/facts/ [Accessed 7 Jan. 2019].

Pew Research Center's Religion \& Public Life Project. (2019). Muslim educational attainment around the world. [online] Available at: http://www.pewforum.org/2016/12/13/muslim-educational-attainment/\#gender-differences-remain-despite-substantial-gains-for-women-across-generations [Accessed 4 Jan. 2019].

UNESCO. 2018. [online] Available at: <https://en.unesco.org/sites/default/files/financing. pdf> [Accessed 17 May 2020].

Wadud, A. (2006). Aishah's Legacy: The Struggle for Women Rights within Islam in The New Voices of Islam: Rethinking Politics and Modernity: a Reader. Berkeley: University of California Press, pp.201-204.

Watt, W. (1989). Islamic Fundamentalism and Modernity. London: Routledge, pp.114-117.

World Bank. n.d. World Bank. [online] Available at: <http://documents.worldbank.org/ curated/en/280721531831663216/pdf/124921-REVISED-AFGHANISTANPROMOTINGEDUCATIONPublication.pdf> [Accessed 17 May 2020].

Yousafzai, M. and Lam, C. (2013). I Am Malala. 1st ed. London: Orion Publishing Group. pp.95 